\title{
Glycogenesis and de novo lipid synthesis from dietary starch in juvenile gilthead sea bream (Sparus aurata) quantified with stable isotopes
}

\author{
Kim S. Ekmann ${ }^{1 *}$, Johanne Dalsgaard ${ }^{1}$, Jørgen Holm², Patrick J. Campbell ${ }^{3}$ and Peter V. Skov ${ }^{1}$ \\ ${ }^{1}$ Technical University of Denmark, DTU Aqua, Section for Aquaculture, The North Sea Research Centre, PO Box 101, \\ DK-9850 Hirtshals, Denmark \\ ${ }^{2}$ BioMar A/S, Mylius Erichsensvej 35, DK-7330 Brande, Denmark \\ ${ }^{3}$ BioMar Limited, North Shore Road, Grangemouth Docks, Grangemouth FK3 8UL, UK \\ (Submitted 14 June 2012 - Final revision received 20 August 2012 - Accepted 28 August 2012 - First published online 27 November 2012)
}

\section{Abstract}

The effects of replacing a digestible energy source from fat (fish oil) with carbohydrate (wheat starch) on performance, glycogenesis and de novo lipogenesis was examined in triplicate groups of juvenile gilthead sea bream (Sparus aurata), fed four extruded experimental diets. In order to trace the metabolic fate of dietary starch, $0.7 \%$ wheat starch was replaced with isotope-labelled starch $\left(>98 \%{ }^{13} \mathrm{C}\right)$. Fish were fed the experimental diets for three consecutive $10 \mathrm{~d}$ periods, and isotope ratio MS was applied to quantify ${ }^{13} \mathrm{C}$ enrichment of liver and whole-body glycogen and lipid pools over the three feeding periods. Glycogenesis originating from dietary starch accounted for up to 68.8 and $38.8 \%$ of the liver and whole-body glycogen pools, respectively, while up to $16.7 \%$ of the liver lipid could be attributed to dietary starch. Between 5 and $8 \%$ of dietary starch carbon was recovered in whole-body lipid, and estimated deposition rates of de novo synthesised lipid originating from starch ranged from 18.7 to $123.7 \mathrm{mg} / \mathrm{kg}$ biomass per d. Dietary treatments did not significantly affect growth, feed performance or body composition of the fish, while the hepatosomatic index and glycogen content of whole fish and livers correlated directly with dietary starch inclusion level. The study suggests that gilthead sea bream efficiently synthesises glycogen from both dietary starch and endogenous sources. In contrast, lipogenesis from carbon derived from starch seems to play a minor role in overall lipid synthesis and deposition under the specified experimental conditions.

Key words: Gilthead sea bream: Stable isotopes: Starch utilisation: Glycogenesis: Lipogenesis

The rapid growth of the aquaculture industry over the last 30 years and the concomitant increasing demand for compound aquaculture feeds have adversely influenced both commodity prices and raised sustainability issues concerning utilisation of natural resources from industrial fisheries such as fishmeal and fish oil ${ }^{(1,2)}$. As a consequence, a substantial number of studies have been carried out to elucidate the nutritional value of alternative nutrient sources, such as vegetable proteins ${ }^{(3)}$ and oils ${ }^{(4,5)}$, animal by-products ${ }^{(6,7)}$ or single-cell organisms ${ }^{(8-10)}$, as replacements for fishmeal or fish oil in commercial aquaculture diets. Although many of these alternatives have proven to be competitive substitutes to fishmeal or fish oil in terms of price cost, some may raise nutritional, safety or ethical concerns ${ }^{(3,11-13)}$ regarding their use in the fish feed industry.

The natural diet of most aquacultured carnivorous fish species typically has a protein- and lipid-rich nutritional profile, abundant in essential amino acids and fatty acids and practically devoid of carbohydrates or anti-nutrients. Thus, introduction of dietary vegetable raw materials containing relatively high amounts of carbohydrates and possibly associated anti-nutrients may pose a challenge to the carnivorous nature of the digestive processes in these species ${ }^{(14,15)}$. In contrast, several studies on gilthead sea bream (Sparus aurata) have reported excellent starch digestibility coefficients ${ }^{(16-18)}$, as well as presence and activity of the major enzymes of the glycolytic pathway ${ }^{(17,19-21)}$, indicating a possible efficient utilisation of dietary starch for energy purposes. However, an apparently prolonged postprandial hyperglycaemia and accumulation of glycogen in muscle and liver tissues ${ }^{(17,19,21,22)}$ suggest an imbalance between digestive/glycogenetic and glycogenolytic/glycolytic activity associated with feeding high-carbohydrate diets to this species. Studies on dietary carbohydrate utilisation in gilthead sea bream have focused

\footnotetext{
Abbreviations: ADC, apparent digestibility coefficient; APE, atom percent excess; DE, digestible energy; DP, digestible protein; FI, feed intake; ISO, International Organisation for Standardisation; LDR, deposition rate of lipid derived from starch; RSCL, recovery of starch carbon in the lipid fraction; TME, theoretical maximum enrichment.
}

*Corresponding author: K. S. Ekmann, fax +45 35883260, email ksek@aqua.dtu.dk 
on effects of starch origin, processing and inclusion levels on carbohydrate digestibility, growth performance, feed conversion or nutrient retention efficiencies ${ }^{(16,18,23)}$, while other studies have also assessed the regulatory effects of dietary digestible carbohydrate on activity of liver enzymes involved in glycolysis, gluconeogenesis, glycogenesis, lipogenesis and amino acid catabolism ${ }^{(17,19-21,24-29)}$. However, as dietary carbohydrate, besides fuelling the glycolytic pathway, can precede de novo lipogenesis, glycogenesis or, as recently found in rainbow trout (Oncorbynchus mykiss), donate carbon backbones for protein synthesis ${ }^{(30)}$, it is difficult to quantitatively conclude on the fate of dietary carbohydrates. Similarly, studies on the key enzymes of carbohydrate metabolism typically examine enzyme activity as an indicator of metabolite fluxes, but does not quantify end products or determine their origin.

The technique of using stable isotopes in nutritional studies dates back to almost 80 years $^{(31)}$ and makes it possible to trace the fate of various compounds in the animal body, assuming that the tracer behaves functionally similar to the tracee, but still can be distinguished from the tracee by measurement. In fish, isotope-labelled carbohydrates have been previously administered to Atlantic cod (Gadus morbua) ${ }^{(32)}$, rainbow trout $^{(30,33)}$, Atlantic halibut (Hippoglossus bippoglossus) ${ }^{(34)}$ and Atlantic salmon (Salmo salar) ${ }^{(35)}$ as a single oral bolus or administered intraperitoneally, allowing researchers to determine the metabolic fate of carbohydrates and estimate synthesis rates of their derived metabolites. More recently, ${ }^{2} \mathrm{H}$-labelled water has also been employed as a tracer in a study investigating glucose metabolism of European seabass (Dicentrarchus labrax) $^{(36)}$.

The purpose of the present study was to quantify the magnitude of de novo lipogenesis and glycogenesis from dietary starch in gilthead sea bream using ${ }^{13} \mathrm{C}$-labelled starch. To achieve this, gilthead sea bream were fed four diets formulated to be similar in digestible protein (DP) and digestible energy (DE), but gradually increasing the proportion of DE supplied from fat (fish oil) with DE from starch (wheat starch) enriched with uniformly labelled ${ }^{13} \mathrm{C}$ starch. The gradual ${ }^{13} \mathrm{C}$ enrichment of liver and whole-body glycogen and lipid pools over a period of $30 \mathrm{~d}$ was used to estimate starch utilisation and quantify deposition rate of starch carbon for lipogenesis, and to determine the overall significance of dietary starch in liver and whole-body glycogen and lipid pools including their turnover rates.

\section{Materials and methods}

\section{Culture conditions and fish}

Gilthead sea bream, with an average individual mass of approximately $75 \mathrm{~g}$, were stocked in a recirculated aquaculture system comprising twelve fibre glass tanks with a volume of 800 litres each at a stocking density of twenty-nine fish per tank (BioMar research facility, The North Sea Research Centre, Hirtshals, Denmark). The tanks were designed to quickly and efficiently remove faeces and uneaten feed pellets from tank water via a central bottom drain. Externally mounted swirl separators made it possible to collect and quantify uneaten feed pellets. The trial facility was supplied with filtered North Sea water with a salinity of $34 \mathrm{~g} / \mathrm{l}$, and temperature was kept at $24^{\circ} \mathrm{C}$ throughout the experiment. Water quality was monitored daily, maintaining $\mathrm{O}_{2}$ saturation between 80 and $100 \%$, ammonium below $1.0 \mathrm{mg} / \mathrm{l}$, nitrite below $1.0 \mathrm{mg} / \mathrm{l}$ and nitrate below $100 \mathrm{mg} / \mathrm{l}$. The $\mathrm{pH}$ was adjusted to $7 \cdot 0$ using sodium bicarbonate when necessary. Tanks were supplied with system water at a flow rate of 1200 litres/tank per h. A $14 \mathrm{~h}$ light $-10 \mathrm{~h}$ dark photoperiod was maintained throughout the trial.

In parallel to the ${ }^{13} \mathrm{C}$ enrichment trial, another twelve tanks of the same recirculated aquaculture system were stocked with gilthead sea bream, with an individual mass of approximately $200 \mathrm{~g}$ at a stocking density of fifty fish per tank. The sole purpose of these fish was to determine apparent digestibility coefficients (ADC) of macronutrients and stable carbon isotopes $\left({ }^{13} \mathrm{C}\right.$ and $\left.{ }^{12} \mathrm{C}\right)$ of the diets.

\section{Experimental diets}

Four diets were prepared using the Allix ${ }^{2}$ feed formulation software (A-systems S.A.) (Table 1). The four diets named A, B, C and D were formulated to contain 60, 120, 180 and $240 \mathrm{~g} \mathrm{starch} / \mathrm{kg}$ feed, respectively. In all diets, $0.7 \%$ of the starch was replaced by uniformly ${ }^{13} \mathrm{C}$-labelled $\left(>98 \%{ }^{13} \mathrm{C}\right)$ starch (Cambridge Isotope Laboratories, Inc.). Fish oil and cellulose were used to balance dietary energy levels. The diets were supplemented with a vitamin and mineral premix, as well as monocalcium phosphate. Guar gum was added $(5 \mathrm{~g} / \mathrm{kg})$ to enhance pellet stability and accurately quantify feed waste, and yttrium oxide $\left(\mathrm{Y}_{2} \mathrm{O}_{3}\right)$ was added $(0 \cdot 3 \mathrm{~g} / \mathrm{kg})$ as an inert marker enabling indirect measurements of nutrient and stable isotope digestibility. Diets were prepared at the Danish Technological Institute using a twin screw extruder (Contina 37; Werner \& Pfleiderer) to produce $3 \mathrm{~mm}$ pellets. Following extrusion, diets were dried, vacuum coated with fish oil and cooled.

\section{Experimental procedures}

The trial comprised three consecutive feeding periods of $10 \mathrm{~d}$ each (thirty feeding days in total), feeding each of the four experimental diets to three replicate tanks (i.e. twelve tanks in all). Six randomly chosen fish were removed from each of the twelve tanks at start-up (day 0), euthanised using $250 \mathrm{mg} / \mathrm{l}$ tricaine methanesulfonate (MS-222), weighed and immediately frozen in liquid $\mathrm{N}_{2}$. The fish were pooled at tank level and stored at $-20^{\circ} \mathrm{C}$ until analysis, constituting the initial fish samples. Remaining fish in each tank were weighed, and the four experimental diets were subsequently fed to triplicate tanks for $10 \mathrm{~d}$ at a daily ration adjusted according to the expected biomass in each tank (approximately $1 \cdot 3 \% / \mathrm{d}$ ). Fish were fed from 08.00 to 14.00 hours using automatic belt feeders, and any uneaten feed was collected daily to calculate the actual feed intake (FI). At the end of the feeding period, fish were starved for $24 \mathrm{~h}$ (day 11) and six randomly 
Table 1. Diet formulation and chemical composition of experimental diets

\begin{tabular}{|c|c|c|c|c|}
\hline Diet & A & B & C & D \\
\hline \multicolumn{5}{|l|}{ Ingredients $(\mathrm{g} / \mathrm{kg})^{*}$} \\
\hline Fishmeal & 607 & 607 & 607 & 608 \\
\hline Fish oil & 152 & 127 & 103 & 78 \\
\hline Wheat starch & 68 & 136 & 204 & 272 \\
\hline Cellulose & 158 & 114 & 70 & 26 \\
\hline Guar gum & 5 & 5 & 5 & 5 \\
\hline Vitamin and mineral mix & 3 & 3 & 3 & 3 \\
\hline Monocalcium phosphate & 6 & 6 & 6 & 6 \\
\hline${ }^{13} \mathrm{C}$-labelled starch $\dagger$ & 0.3 & 0.6 & 0.9 & 1.2 \\
\hline Yttrium oxide & 0.3 & 0.3 & 0.3 & 0.3 \\
\hline \multicolumn{5}{|l|}{ Proximate composition $(\mathrm{g} / \mathrm{kg})$} \\
\hline Protein & 461 & 461 & 462 & 458 \\
\hline Fat & 218 & 189 & 168 & 139 \\
\hline Starch & 54 & 121 & 179 & 236 \\
\hline DM & 964 & 952 & 956 & 951 \\
\hline Ash & 80 & 80 & 81 & 80 \\
\hline $\mathrm{P}$ & 15 & 15 & 15 & 15 \\
\hline \multicolumn{5}{|l|}{ EAA $(g / k g)$} \\
\hline Arg & $25 \cdot 2$ & $25 \cdot 2$ & $25 \cdot 1$ & $25 \cdot 0$ \\
\hline His & 11.6 & 11.5 & 11.4 & 11.4 \\
\hline Ile & $19 \cdot 6$ & $19 \cdot 6$ & $19 \cdot 4$ & 19.5 \\
\hline Leu & 34.5 & 34.4 & 34.3 & 33.8 \\
\hline Val & 24.0 & $23 \cdot 8$ & 23.5 & 23.2 \\
\hline Lys & 37.9 & 37.9 & $37 \cdot 2$ & $37 \cdot 2$ \\
\hline Met+Cys & 19.2 & 18.9 & 18.9 & 18.5 \\
\hline Phe & $18 \cdot 3$ & 18.4 & $18 \cdot 2$ & $18 \cdot 1$ \\
\hline Thr & 21.2 & 20.9 & $20 \cdot 8$ & $20 \cdot 3$ \\
\hline Trp & $5 \cdot 6$ & $5 \cdot 6$ & $5 \cdot 7$ & $5 \cdot 5$ \\
\hline \multicolumn{5}{|c|}{ Calculated dietary energy $(\mathrm{MJ} / \mathrm{kg})$} \\
\hline GE $\ddagger$ & 23.1 & $22 \cdot 3$ & 21.9 & $21 \cdot 1$ \\
\hline DE§ & $17 \cdot 9$ & $18 \cdot 2$ & $18 \cdot 4$ & 18.9 \\
\hline
\end{tabular}

EAA, essential amino acids; GE, gross energy; DE, digestible energy.

*Fishmeal: TripleNine Fish Protein, Esbjerg, Denmark; fish oil: South American (Peru); wheat starch: Cargill, Belgium; cellulose: Vitacel R200, Rettenmaier und Söhne GmbH, Germany; guar gum: HV200, LCH A/S, Frederiksberg, Denmark; ${ }^{13} \mathrm{C}$-labelled starch: Cambridge Isotope Laboratories, Inc., Algal starch $\left(\mathrm{U}-{ }^{13} \mathrm{C}\right.$ $98 \%+$ ), catalogue no. CLM-1699-0, Andover, MA, USA; vitamin and mineral mix is estimated to meet the requirements according to the US National Research Council recommendations ${ }^{(62)}$.

†Each of the four diets was produced in a ${ }^{13} \mathrm{C}$-enriched version (adding ${ }^{13} \mathrm{C}$-labelled starch) and a non-enriched version (adding wheat starch) in order to determine ${ }^{13} \mathrm{C}$ atom \% excess of experimental diets.

$\ddagger \mathrm{GE}(\mathrm{MJ} / \mathrm{kg})$ was calculated as the sum of the dietary content of protein, lipid and nitrogen-free extract (NFE), multiplied by their respective energetic values upon complete oxidation ${ }^{(63)}: \mathrm{GE}=\left(P_{\text {diet }} \times 23.66\right)+\left(L_{\text {diet }} \times 39.57\right)+\left(\mathrm{NFE}_{\text {diet }} \times 17.58\right)$ where $P_{\text {diet }}, L_{\text {diet }}$ and NFE diet $_{\text {r }}$ refer to the dietary protein, lipid and NFE content (\%), respectively. NFE was calculated as the sum of dietary protein, lipid, ash and water deducted from $100 \%$ (by difference).

$\S D E(\mathrm{MJ} / \mathrm{kg})$ content was calculated as the dietary gross energy, but with the apparent digestibility coefficients (ADC) of each nutrient multiplied into their respective terms: $\mathrm{DE}=\left(P_{\text {diet }} \times 23.66 \times \mathrm{ADC}_{\text {protein }}\right)+\left(L_{\text {diet }} \times 39.57 \times\right.$ $\left.A D C_{\text {lipid }}\right)+\left(S_{\text {diet }} \times 17.58 \times \mathrm{ADC}_{\text {starch }}\right)$, where $S_{\text {diet }}$ is the dietary starch content, and $A D C_{\text {protein, }} A D C_{\text {lipid }}$ and $A D C_{\text {starch }}$ are the $A D C$ of protein, lipid and starch, respectively.

chosen fish were removed from each tank (day 12), euthanised, weighed and immediately frozen in liquid $\mathrm{N}_{2}$. The fish were pooled at tank level and stored at $-20^{\circ} \mathrm{C}$ until analysis, constituting fish samples after $10 \mathrm{~d}$ of isotopic enrichment. The same procedures were followed during feeding period 2 (days 13-22) and 3 (days 25-34), yielding a total of $4 \times 12$ fish samples throughout the trial. The five remaining fish in each tank at the end of the trial (day 34) were weighed, euthanised and discarded.

ADC of dietary macronutrients and stable carbon isotopes $\left({ }^{13} \mathrm{C}\right.$ and $\left.{ }^{12} \mathrm{C}\right)$ were determined using the stripping/inert marker method ${ }^{(37)}$ with yttrium as the inert marker. The ADC determinations were carried out on larger (200 g) fish in order to obtain sufficient quantities of faeces for chemical analysis, and also because larger fish are easier to handle, reducing the risk of contaminating samples with mucus, urine and scales. The four experimental diets were fed to triplicate tanks for 3 weeks, applying a feeding ration of $1.5 \%$ of the estimated biomass per $d$. The final meal was administered $18 \mathrm{~h}$ prior to stripping, when the fish were anaesthetised using MS-222 (50 mg/l) and a gentle bi-lateral pressure was applied to the hindgut in order to provoke defecation. Faeces obtained from fish within each tank were pooled and immediately frozen at $-20^{\circ} \mathrm{C}$.

All studies were carried out in accordance to EC directive 86/609/EEC for animal experiments ${ }^{(38)}$

\section{Sample preparation and chemical and isotopic analysis}

Feed samples. Feed samples were homogenised prior to analysis using a Krups Speedy Pro homogeniser. Crude protein was determined according to the International Organisation for Standardisation (ISO) ${ }^{(39)}$, crude fat according to Bligh \& Dyer ${ }^{(40)}$ and DM and ash according to Kolar ${ }^{(41)}$ Yttrium and $\mathrm{P}$ were determined according to $\mathrm{ISO}^{(42)}$ and Danish Standards ${ }^{(43)}$, while amino acids were determined according to the European Commission ${ }^{(44)}$ and ISO $^{(45)}$ Starch analyses were carried out according to the method by Bach Knudsen ${ }^{(46)}$. Aliquots of the homogenised feed samples were lyophilised and finely ground using a mortar and pestle prior to determination of ${ }^{13} \mathrm{C}$ isotope enrichment and elemental carbon.

Faecal samples. Faecal samples were lyophilised prior to analysis using a Christ Beta 2-16 freeze dryer (Martin Christ Gefriertrocknungsanlagen $\mathrm{GmbH}$ ). Faecal protein was determined by elemental analysis, according to the method described in the section 'isotopic analysis', assuming that protein equals $6 \cdot 25 \times \mathrm{N}$. Faecal lipid was determined according to Bligh \& Dyer ${ }^{(40)}$. Faecal starch was determined using a BioVision Starch assay kit (catalogue no. K647-100, Tecan GENios micro plate reader (Austria) fitted with a $570 \mathrm{~nm}$ colorimetric filter) and yttrium was determined according to ISO $^{(42)}$ and Danish Standards ${ }^{(43)}$. Aliquots of the faeces samples were lyophilised and finely ground using a mortar and pestle prior to determination of ${ }^{13} \mathrm{C}$ isotope enrichment and elemental carbon and nitrogen.

Fish samples. Fish sampled initially $(1 \times 12$ samples $)$ and by the end of each feeding period $(3 \times 12$ samples $)$ were partly thawed and fractionated into livers, viscera (excluding liver) and carcass. Tissues were kept at or below $0^{\circ} \mathrm{C}$ during fractionation in order to avoid enzymatic degradation of glycogen, and the different fractions were immediately refrozen at $-20^{\circ} \mathrm{C}$ prior to further analysis. Liver samples were homogenised in a frozen state using a mortar and pestle, and frozen carcass and viscera fractions were pooled at tank level and homogenised for $60 \mathrm{~s}$ using a Tecator 1094 homogeniser (Tecator $\mathrm{AB}$ ). An aliquot of each sample was further homogenised for 30 s using a Büchi Mixer B-400 (BÜCHI Labortechnik AG). The two fractions (livers and carcass/viscera) were chemically 
and isotopically analysed separately according to the procedures described later. In the following, the designation 'whole fish' and associated metabolite pools refer to the summed whole body mass contribution of the two fractions (i.e. livers and carcass/viscera) multiplied by their respective analytical values. Crude protein, crude fat, DM and ash of the two fractions were determined as described for feed samples, while glycogen was determined using a BioVision glycogen assay kit (catalogue no. K646-100/Tecan GENios micro plate reader (Austria) fitted with a $570 \mathrm{~nm}$ colorimetric filter). Isolation of glycogen was done according to Good et $a l .{ }^{(47)}$. Isolated glycogen samples were subsequently lyophilised prior to determination of ${ }^{13} \mathrm{C}$ isotope enrichment and elemental carbon. Lipid samples for ${ }^{13} \mathrm{C}$ isotope enrichment and elemental carbon analysis were obtained during the lipid extraction process of the Bligh \& Dyer procedure ${ }^{(40)}$.

Isotopic analysis. Feed samples, isolated liver glycogen and lipid and isolated carcass/viscera glycogen and lipid samples were all analysed for ${ }^{13} \mathrm{C}$ isotope enrichment and elemental carbon, while faecal samples were analysed for ${ }^{13} \mathrm{C}$ isotope enrichment and elemental carbon and nitrogen. Prior to isotopic analysis, aliquots of all samples were packed and weighed into tin capsules (Standard Weight Pressed Tin Capsules $5 \times 3.5 \mathrm{~mm}$, catalogue no. D1002; Elemental Microanalysis Limited) using an analytical microbalance (Mettler Toledo MT5; Mettler Toledo Inc.). All carbon isotope and elemental carbon and nitrogen analyses were carried out using a Thermoquest EA1110 CHNS-O elemental analyser coupled to a Thermo Scientific Delta V advantage isotope ratio mass spectrometer via a Thermo Scientific ConFlo IV module.

\section{Calculations}

Stable ${ }^{13} \mathrm{C}$ isotope enrichment $\left(\delta^{13} \mathrm{C}, \% 0\right)$ of samples was calculated as:

$$
\delta^{13} \mathrm{C}=\left(\left(R_{\text {sample }}-R_{\text {standard }}\right) /\left(R_{\text {standard }}\right)\right) \times 1000,
$$

where $R_{\text {sample }}$ is the ${ }^{13} \mathrm{C}:{ }^{12} \mathrm{C}$ ratio of the sample and $R_{\text {standard }}$ is the ${ }^{13} \mathrm{C}:{ }^{12} \mathrm{C}$ ratio of the reference standard calibrated against the international standard V-PDB (Pee Dee Belemnite).

The ${ }^{13} \mathrm{C}$ atom percent excess (APE, \%) of the samples was determined as the difference between the atom percentage $\left({ }^{13} \mathrm{C}\right.$ atm $\left.\%\right)$ of the enriched sample and the unenriched sample ('blank'), as shown below:

$$
\text { APE }\left[{ }^{13} \mathrm{C}\right]={ }^{13} \mathrm{C} \text { atm } \%_{\text {sample }}-{ }^{13} \mathrm{C} \text { atm } \%_{\text {blank }} \text {. }
$$

Atomic percentages were calculated as:

$$
\begin{aligned}
{ }^{13} \mathrm{Catm} \%= & \left(100 \times \mathrm{AR} \times\left(\left(\delta^{13} \mathrm{C} / 1000\right)+1\right)\right) /(1+\mathrm{AR} \\
& \left.\times\left(\left(\delta^{13} \mathrm{C} / 1000\right)+1\right)\right),
\end{aligned}
$$

where AR is the absolute ${ }^{13} \mathrm{C}:{ }^{12} \mathrm{C}$ ratio of V-PDB (0.0112372), as given by $\mathrm{Craig}^{(48)}$.

Deposition rate of lipid derived from starch (LDR, mg/kg biomass per $\mathrm{d}$ ) was calculated as:

$$
\begin{aligned}
\mathrm{LDR}= & ((\mathrm{mg} \text { lipid synthesised from starch } \\
& \left.\left.\left(t_{i}-t_{0}\right) / \mathrm{kg} \text { biomass }\left(t_{i}\right)\right) / t_{i}-t_{0}\right),
\end{aligned}
$$

where mg lipid synthesised from starch $=$ (g carbon of starch origin found in whole-body lipid fraction $\left(t_{\mathrm{i}}\right) / \%$ carbon in whole-body lipid fraction $\left.\left(t_{i}\right)\right) \times 1000$.

The carbon content of the whole-body lipid fraction was determined from the MS analysis, while the amount of carbon deriving from starch found in the lipid fraction of the fish was determined as:

$$
\begin{aligned}
& \mathrm{g} \text { lipid } \mathrm{C}_{(\text {starch origin) }}=\left(\mathrm{g} \text { lipid }{ }^{13} \mathrm{C} \text { in excess } /\right. \\
& \left.\%{ }^{13} \mathrm{C} \text { enrichment level of dietary starch }\right),
\end{aligned}
$$

where

$$
\begin{aligned}
\text { Lipid }^{13} \mathrm{C} \text { in excess }= & \left(\mathrm{g} \text { biomass }\left(t_{i}\right)\right. \\
& \times \% \text { whole-fish lipid content }\left(t_{i}\right) \\
& \times \% \text { carbon in whole-fish lipid }\left(t_{i}\right) \\
& \left.\times \% \operatorname{APE}_{\text {lipid }}\left(t_{i}\right)\right)
\end{aligned}
$$

and

${ }^{13} \mathrm{C}$ enrichment level of dietary starch

$=\left(\% \mathrm{APE}_{\text {diet }} /((\%\right.$ dietary starch content $\times \%$ carbon content of dietary starch)/\%carbon in feed)).

Recovery of starch carbon in whole-fish lipid fraction (RSCL, \%) was calculated as:

$\mathrm{RSCL}=\mathrm{g}$ lipid $\mathrm{C}_{(\text {starch origin) }} / \mathrm{g}$ digestible starch carbon intake.

\section{Statistical analysis}

Data on specific growth rates, feed conversion ratios, FI, hepatosomatic indices, viscerosomatic indices, ADC and the chemical composition of whole fish and livers were subjected to one-way ANOVA analysis, assessing significant differences among means using Duncan's multiple range test ${ }^{(49)}$. A $t$ test was used for testing differences between means in the ADC of the two carbon isotopes. A probability of $P<0.05$ was considered significant in all analyses. Data on LDR and RSCL of whole fish were subjected to two-way ANOVA analysis to test for main effects of, and interactions between, diet and isotopic enrichment period, respectively. Significant differences found in main effect (when not interacting with other main effects) were subsequently assessed using Duncan's multiple range test. Regression analysis of temporal increase in APE in liver lipid and glycogen and in whole-fish glycogen pools was performed using a two-parameter exponential rise to maximum equation:

$$
y=a \times(1-\exp (-b \times x)),
$$

where $y$ is the ${ }^{13} \mathrm{C}$ APE, $x$ is enrichment time and $a$ and $b$ are constants. Regression analysis of the temporal increase in whole-body lipid APE gave a better fit when employing a linear regression:

$$
y=b+a \times x,
$$

where $y$ is the ${ }^{13} \mathrm{C}$ APE, $x$ is enrichment time and $a$ and $b$ are constants. All statistical analyses were performed using the WinSTAT ${ }^{\circledR}$ for Microsoft ${ }^{\circledR}$ Excel, version 2009.1 software package (R. Fitch Software). 
Table 2. Elemental carbon and stable carbon isotope analysis of the four experimental diets

(Mean values and standard deviations, $n$ 3)

\begin{tabular}{|c|c|c|c|c|c|c|c|c|}
\hline \multirow[t]{2}{*}{ Diet... } & \multicolumn{2}{|c|}{$A$} & \multicolumn{2}{|c|}{$B$} & \multicolumn{2}{|c|}{$\mathrm{C}$} & \multicolumn{2}{|c|}{$\mathrm{D}$} \\
\hline & Mean & SD & Mean & SD & Mean & SD & Mean & SD \\
\hline \multicolumn{9}{|l|}{ Carbon content of diet (\%) } \\
\hline Non-enriched diets & $47 \cdot 87$ & 0.59 & 47.42 & 0.35 & $46 \cdot 73$ & $0 \cdot 27$ & $45 \cdot 57$ & 0.03 \\
\hline${ }^{13} \mathrm{C}$-enriched diets & $47 \cdot 82$ & 0.47 & $47 \cdot 00$ & 0.54 & $46 \cdot 14$ & $0 \cdot 19$ & $45 \cdot 19$ & $0 \cdot 15$ \\
\hline \multicolumn{9}{|l|}{$\delta^{13} \mathrm{C}$ values of diets (\%०) } \\
\hline Non-enriched diets & $-21 \cdot 50$ & 0.04 & $-21 \cdot 65$ & 0.04 & -21.59 & 0.13 & -21.55 & 0.02 \\
\hline${ }^{13} \mathrm{C}$-enriched diets & $16 \cdot 36$ & 0.38 & $48 \cdot 21$ & 1.84 & 87.75 & 1.82 & $113 \cdot 89$ & 2.59 \\
\hline \multicolumn{9}{|l|}{${ }^{13} \mathrm{C}$ APE $(\%)$} \\
\hline${ }^{13} \mathrm{C}$-enriched diets & 0.0416 & 0.0004 & 0.0767 & 0.0020 & 0.1201 & 0.0021 & 0.1487 & 0.0028 \\
\hline${ }^{13} \mathrm{C}$ enrichment of starch carbon (\%) & 0.831 & 0.006 & 0.672 & 0.013 & 0.698 & 0.012 & 0.641 & 0.011 \\
\hline
\end{tabular}

APE, atom percent excess.

\section{Results}

\section{Diets and dietary ${ }^{13} \mathrm{C}$ enrichment}

The composition and chemical analysis of the experimental diets are shown in Table 1 . The crude protein content of the diets was very similar $(458-462 \mathrm{~g} / \mathrm{kg})$. The lipid content decreased from $218 \mathrm{~g} / \mathrm{kg}$ in diet A to $139 \mathrm{~g} / \mathrm{kg}$ in diet $\mathrm{D}$, and the crude starch content increased from $54 \mathrm{~g} / \mathrm{kg}$ in diet A to $236 \mathrm{~g} / \mathrm{kg}$ in diet D. Data from the stable isotope analyses are presented in Table 2 . The dietary carbon content ranged from $45 \cdot 2$ to $47 \cdot 9 \%$. The $\delta^{13} \mathrm{C}$ values of the non-enriched diets ranged between -21.7 and $-21.5 \%$, while $\delta^{13} \mathrm{C}$ values of the enriched diets were measured as $16 \cdot 4,48 \cdot 2$, 87.8 and $113.9 \%$ for diets $\mathrm{A}, \mathrm{B}, \mathrm{C}$ and $\mathrm{D}$, corresponding to
${ }^{13} \mathrm{C}$ APE of $0 \cdot 04,0 \cdot 08,0 \cdot 12$ and $0 \cdot 15 \%$, respectively. The measured ${ }^{13} \mathrm{C}$ enrichment of starch carbon was $0.83,0.67$, 0.70 and $0.64 \%$ for diets A, B, C and D, respectively.

\section{${ }^{13} \mathrm{C}$ enrichment of whole fish and livers}

Isotope enrichment of the liver glycogen and liver lipid pools and of the whole-body glycogen and lipid pools are presented in Fig. 1, while the associated regression equations are presented in Table 3. The regression equations fitted the data very well, with coefficients of determination $\left(r^{2}\right)$ ranging between 0.828 and 1.000. The curves in Fig. 1(a)-(c) display saturation kinetics, moving asymptotically towards a value deduced from the equation constant $a$ (hereafter referred to

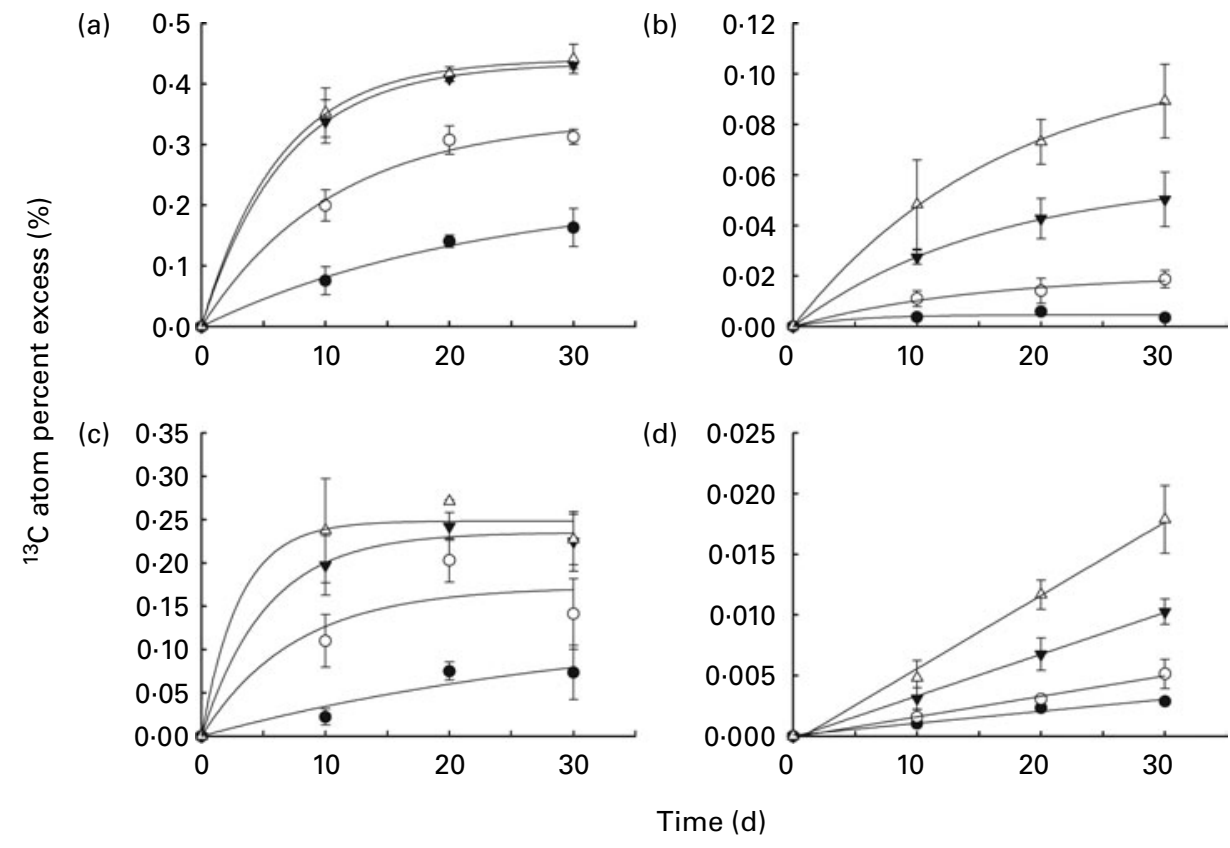

Fig. 1. ${ }^{13} \mathrm{C}$ atom percent excess (\%) measured in (a) liver glycogen pool, (b) liver lipid pool, (c) whole-body glycogen pool and (d) whole-body lipid pool, measured after 10,20 and $30 \mathrm{~d}$ of dietary ${ }^{13} \mathrm{C}$ starch enrichment. Associated regression analyses are presented in Table 3 . Values are means and standard deviations represented by vertical bars $(n 3)$. $\bullet$, Diet A; O, diet B; $\mathbf{\nabla}$, diet C; $\Delta$, diet D. 
Table 3. ${ }^{13} \mathrm{C}$ atom percent excess (APE) regression equation coefficients and constants calculated from regression analysis of liver glycogen and lipid pools and whole-body glycogen and lipid pools

\begin{tabular}{|c|c|c|c|c|c|c|c|}
\hline Metabolite pool & Dietary treatment & $a$ & $b$ & $r^{2}$ & $\operatorname{APE}_{\lim }(t \rightarrow \infty)^{\star}$ & $t_{95 \%} \dagger$ & Enriched $(\%$ of TME $) \ddagger$ \\
\hline \multicolumn{8}{|c|}{ Liver glycogen pool } \\
\hline & A & $0 \cdot 226$ & 0.045 & 0.994 & $0.226 \%$ & 67 & $27 \cdot 2 \%$ \\
\hline & $\mathrm{B}$ & 0.343 & 0.094 & 0.993 & $0.343 \%$ & 32 & $51.0 \%$ \\
\hline & C & 0.435 & $0 \cdot 150$ & 1.000 & $0.435 \%$ & 20 & $62.3 \%$ \\
\hline & $\mathrm{D}$ & 0.441 & $0 \cdot 159$ & $1 \cdot 000$ & $0.441 \%$ & 19 & $68.8 \%$ \\
\hline \multicolumn{8}{|l|}{ Liver lipid pool } \\
\hline & A & 0.005 & 0.206 & 0.828 & $0.005 \%$ & 15 & $0.6 \%$ \\
\hline & $\mathrm{B}$ & 0.021 & 0.068 & 0.985 & $0.021 \%$ & 44 & $3.1 \%$ \\
\hline & C & 0.060 & 0.062 & $1 \cdot 000$ & $0.060 \%$ & 48 & $8.6 \%$ \\
\hline & $\mathrm{D}$ & 0.107 & 0.059 & 0.999 & $0.107 \%$ & 51 & $16 \cdot 7 \%$ \\
\hline \multicolumn{8}{|c|}{ Whole-body glycogen pool } \\
\hline & A & $0 \cdot 137$ & 0.029 & 0.904 & $0.137 \%$ & 103 & $16.5 \%$ \\
\hline & $\mathrm{B}$ & 0.172 & 0.133 & 0.867 & $0.172 \%$ & 23 & $25.6 \%$ \\
\hline & C & 0.235 & 0.191 & 0.993 & $0.235 \%$ & 16 & $33.7 \%$ \\
\hline & $\mathrm{D}$ & $0 \cdot 248$ & 0.327 & 0.979 & $0.248 \%$ & 9 & $38.8 \%$ \\
\hline \multicolumn{8}{|c|}{ Whole-body lipid pool } \\
\hline & A & $1 \times 10^{-4}$ & $8 \times 10^{-5}$ & 0.966 & NA & NA & NA \\
\hline & $\mathrm{B}$ & $2 \times 10^{-4}$ & $-9 \times 10^{-5}$ & 0.991 & NA & NA & NA \\
\hline & C & $3 \times 10^{-4}$ & $-1 \times 10^{-4}$ & 0.999 & NA & NA & NA \\
\hline & D & $6 \times 10^{-4}$ & $-5 \times 10^{-4}$ & 0.993 & NA & NA & NA \\
\hline
\end{tabular}

NA, not available.

${ }^{*} \mathrm{APE} \mathrm{E}_{\lim }(t \rightarrow \infty)$ refers to the ${ }^{13} \mathrm{C}$ APE value asymptotically approached by a metabolite pool when enrichment time goes towards infinity.

$\dagger t_{95}$ refers to the theoretical time (in d) it would take APE of a metabolite pool to reach $95 \%$ of $A P E_{\lim }(t \rightarrow \infty)$. Calculated as $t_{95} \%=\ln (0 \cdot 05) /-b$, where $b$ is the equation constant as given in the table.

$\ddagger$ TME refers to the theoretical maximum ${ }^{13} \mathrm{C}$ enrichment value any given $\mathrm{APE}_{\text {lim }}(t \rightarrow \infty)$ could possibly approach, equalling the ${ }^{13} \mathrm{C}$ enrichment of the starch fraction of the corresponding diet.

as $\left.\operatorname{APE}_{\lim }(t \rightarrow \infty)\right)$. The theoretical maximum enrichment (TME) value any given $\operatorname{APE}_{\text {lim }}(t \rightarrow \infty)$ could possibly approach equalled the ${ }^{13} \mathrm{C}$ enrichment of the starch fraction of the corresponding diet (Table 3), and would only occur if dietary starch was the sole carbon contributor to that metabolite pool. Also, deduced from these equations, the theoretical time, in days, it would take APE to reach $95 \%$ of their respective $\operatorname{APE}_{\text {lim }}(t \rightarrow \infty)$ was designated $t_{95 \%}$ (Table 3 ) and indicated how fast the ${ }^{13} \mathrm{C}$ enrichment of a given metabolite pool reached an equilibrium, which in turn indicated the turnover of that metabolite pool (i.e. low $t_{95} \%$ values indicated high turnover and high $t_{95} \%$ indicated low turnover). Liver glycogen ${ }^{13} \mathrm{C}$ APE values rose exponentially towards an $\mathrm{APE}_{\mathrm{lim}}$ $(t \rightarrow \infty)$ of $0.226,0.343,0.435$ and $0.441 \%$ (Fig. 1(a)), corresponding to $27 \cdot 2,51 \cdot 0,62 \cdot 3$ and $68 \cdot 8 \%$ of the TME for fish fed diets A, B, C and D, respectively. Furthermore, the regression analysis predicted that fish fed diets $\mathrm{A}, \mathrm{B}, \mathrm{C}$ and D would reach $t_{95 \%}$ in $67,32,20$ and $19 \mathrm{~d}$, respectively, of feeding on the enriched diets.

Liver lipid ${ }^{13} \mathrm{C}$ APE values rose exponentially towards APE $\mathrm{E}_{\mathrm{lim}}$ $(t \rightarrow \infty)$ values of $0.005,0.021,0.060$ and $0.107 \%$ (Fig. 1(b)), corresponding to $0 \cdot 6,3 \cdot 1,8.6$ and $16 \cdot 7 \%$ of the TME for fish fed diets A, B, C and D, respectively. Regression analysis on liver lipid APE predicted that fish fed diets A, B, C and D would reach $t_{95} \%$ in $15,44,48$ and $51 \mathrm{~d}$, respectively, of feeding on the enriched diets.

Whole-body glycogen pool APE increased exponentially towards $0 \cdot 137,0 \cdot 172,0.235$ and $0 \cdot 248 \%$ (Fig. 1(c)), corresponding to $16.5,25.6,33.7$ and $38.8 \%$ of the TME for fish fed diets A, B, C and D, respectively. Regression analysis of whole-body glycogen APE predicted that fish fed diets
A, B, C and D would reach $t_{95 \%}$ in $103,23,16$ and $9 \mathrm{~d}$, respectively, of feeding on the enriched diets.

The whole-body lipid ${ }^{13} \mathrm{C}$ APE values all increased linearly with time fed on the enriched diets (Fig. 1(d)), and the rate of enrichment was directly related to the dietary starch content, ranging from 0.0029 (diet A) to 0.0179\% (diet D) after $30 \mathrm{~d}$ of feeding.

\section{Feed intake, growth and feed conversion ratio}

Results on FI, feed conversion and growth are presented in Table 4 . The fish accepted all diets well, and the accumulated feed waste during the three feeding periods was approximately $2 \cdot 2 \%$ of the total amount of feed fed to each tank, irrespective of dietary treatment. No mortality occurred throughout the trial. No significant differences in specific growth rates (ranging from $1 \cdot 19$ to $1 \cdot 29 \% /$ d), feed conversion ratios (ranging from 1.03 to 1.09 ) and FI (ranging from 1.28 to $1.33 \% / \mathrm{d}$ ) were found among the dietary treatments.

\section{Digestibility of macronutrients and carbon isotopes}

The ADC of the diets, as derived from large fish, are shown in Table 4. The protein ADC ranged from 84.8 (diet C) to 91.6\% (diet D), with fish fed diet D having a significantly higher protein digestibility than fish fed the remaining diets. Lipid ADC ranged from $87.0 \%$ in diet A to $90.7 \%$ in diet C, with no significant differences between dietary treatment groups. The apparent digestibility of starch was significantly higher in fish fed diets A and B (99.3 and 99.6\%, respectively) than in fish fed diets C and D ( 97.3 and $96.5 \%$, respectively). There was no difference in the apparent digestibility of 
Table 4. Specific growth rate, feed conversion ratio, daily feed intake and apparent digestibility coefficients (ADC) of macronutrients and stable carbon isotopes

(Mean values and standard deviations, $n 3$ )

\begin{tabular}{|c|c|c|c|c|c|c|c|c|c|}
\hline \multirow[t]{2}{*}{ Diet... } & \multicolumn{2}{|c|}{ A } & \multicolumn{2}{|c|}{ B } & \multicolumn{2}{|c|}{$\mathrm{C}$} & \multicolumn{2}{|c|}{$\mathrm{D}$} & \multirow[b]{2}{*}{$P$} \\
\hline & Mean & SD & Mean & SD & Mean & SD & Mean & SD & \\
\hline \multicolumn{10}{|c|}{ Growth, feed conversion ratios and feed intake } \\
\hline $\operatorname{SGR}(\% / d)^{*}$ & 1.25 & 0.05 & 1.22 & 0.04 & 1.19 & 0.06 & 1.29 & $0 \cdot 10$ & 0.37 \\
\hline FCR $(\mathrm{kg} / \mathrm{kg}) \dagger$ & 1.03 & 0.05 & 1.07 & 0.05 & 1.09 & 0.06 & 1.03 & 0.06 & 0.48 \\
\hline $\mathrm{Fl}(\% / \mathrm{d}) \ddagger$ & 1.28 & 0.01 & 1.31 & 0.02 & 1.30 & 0.02 & 1.33 & 0.03 & 0.11 \\
\hline \multicolumn{10}{|c|}{ ADC of macronutrients $(\%) \S$} \\
\hline Protein & $86 \cdot 7^{\mathrm{a}}$ & 0.1 & $86 \cdot 6^{\mathrm{a}}$ & $2 \cdot 3$ & $84 \cdot 8^{\mathrm{a}}$ & 0.4 & $91.6^{\mathrm{b}}$ & 0.3 & 0.001 \\
\hline Lipid & $87 \cdot 0$ & $3 \cdot 1$ & $89 \cdot 0$ & 0.8 & $90 \cdot 7$ & $2 \cdot 2$ & 90.5 & 3.7 & 0.353 \\
\hline Starch & $99 \cdot 3^{a}$ & 0.2 & $99 \cdot 6^{a}$ & 0.1 & $97 \cdot 3^{\mathrm{b}}$ & 0.3 & $96 \cdot 5^{\mathrm{b}}$ & 0.9 & $<0.001$ \\
\hline \multicolumn{10}{|c|}{ ADC of carbon isotopes $(\%) \S$} \\
\hline${ }^{12} \mathrm{C}$ & $68 \cdot 2$ & $1 \cdot 2$ & \multirow{2}{*}{\multicolumn{2}{|c|}{ NA }} & \multicolumn{2}{|c|}{ NA } & \multirow{2}{*}{\multicolumn{2}{|c|}{ NA }} & \multirow[t]{2}{*}{$0.363 \|$} \\
\hline${ }^{13} \mathrm{C}$ & $69 \cdot 2$ & $1 \cdot 1$ & & & & & & & \\
\hline
\end{tabular}

SGR, specific growth rates; FCR, feed conversion ratios; FI, feed intake; NA, not available.

${ }^{\mathrm{a}, \mathrm{b}}$ Mean values within a row with unlike superscript letters were significantly different $(P<0.05$; Duncan's multiple range test).

${ }^{*}$ SGR calculated according to Hopkins ${ }^{(64)}$ as: $S G R=\ln \left(\right.$ biomass $_{(\mathrm{end})} /$ biomass $\left._{(\text {initial })}\right) /($ days in trial) $) \times 100$

$\dagger \mathrm{FCR}=$ feed consumed/biomass gained.

$\ddagger \mathrm{FI}=$ feed consumed/expected biomass.

$\S$ The $\mathrm{ADC}$ of nutrient $X: \mathrm{ADC}_{(\mathrm{X})}=1-\left(\left(l_{\text {diet }} \times X_{\text {faeces }}\right) /\left(l_{\text {faeces }} \times X_{\text {diet }}\right)\right)$, where $I_{\text {diet }}$ and $I_{\text {faeces }}$ is the yttrium concentration recovered in the die and faeces, respectively, and $X_{\text {faeces }}$ and $X_{\text {diet }}$ is the concentration of $X$ (protein, lipid, starch or carbon isotope) recovered in the faeces and diet, respectively ${ }^{(65)}$.

$\| P$ value is based on a $t$ test comparing the ADC of the two carbon isotopes.

the two carbon isotopes $\left(68 \cdot 2\right.$ and $69 \cdot 2 \%$ for ${ }^{12} \mathrm{C}$ and ${ }^{13} \mathrm{C}$, respectively) determined in the enriched diet $\mathrm{A}$. Based on the study of Windell et al. ${ }^{(50)}$, it was assumed that the ADC derived from larger fish applied to the smaller fish from this trial as well.

\section{Chemical composition of whole fish and livers}

The chemical composition of whole fish and livers at the end of the experiment is presented in Table 5. In whole fish, no significant effects of dietary treatment were seen in the content of crude protein, crude lipid, DM or ash. In contrast, the whole-body glycogen content differed significantly between all dietary treatments, equalling $1 \cdot 8,2 \cdot 5,3 \cdot 4$ and $4 \cdot 3 \mathrm{~g} / \mathrm{kg}$ for fish fed diets A, B, C and D, respectively. There were no significant differences in the content of crude lipid, DM or ash in the liver. The liver protein content was inversely related to the dietary starch content, ranging from $144.4 \mathrm{~g} / \mathrm{kg}$ in fish fed diet A to $109.5 \mathrm{~g} / \mathrm{kg}$ in fish fed diet D. Fish fed diets A and B differed significantly from each other and from fish fed diets $\mathrm{C}$ and $\mathrm{D}$. The liver glycogen content increased with an increasing dietary starch content, being significantly lower in fish fed diet A $(59.0 \mathrm{~g} / \mathrm{kg})$ than in fish fed diets C and D (98.8 and $112.6 \mathrm{~g} / \mathrm{kg}$, respectively), while fish fed diet B $(77.9 \mathrm{~g} / \mathrm{kg})$ had a significantly lower liver glycogen content than fish fed diet $\mathrm{D}$.

Table 5. Chemical composition of whole fish and livers

(Mean values and standard deviations, $n 3$ )

\begin{tabular}{|c|c|c|c|c|c|c|c|c|c|}
\hline \multirow[t]{2}{*}{ Diet. . } & \multicolumn{2}{|c|}{ A } & \multicolumn{2}{|c|}{ B } & \multicolumn{2}{|c|}{$\mathrm{C}$} & \multicolumn{2}{|c|}{ D } & \multirow[b]{2}{*}{$P$} \\
\hline & Mean & SD & Mean & SD & Mean & SD & Mean & SD & \\
\hline \multicolumn{10}{|c|}{ Chemical composition of whole fish $(\mathrm{g} / \mathrm{kg})$} \\
\hline Crude protein & 173.9 & 1.9 & $170 \cdot 4$ & 1.3 & 174.9 & 3.3 & $175 \cdot 8$ & $4 \cdot 0$ & 0.172 \\
\hline Crude lipid & $147 \cdot 4$ & $5 \cdot 7$ & 148.9 & $11 \cdot 0$ & $147 \cdot 0$ & 4.0 & 142.5 & 2.9 & 0.684 \\
\hline DM & $345 \cdot 7$ & 5.9 & $346 \cdot 8$ & $8 \cdot 7$ & 351.6 & 1.0 & $351 \cdot 0$ & 4.9 & 0.537 \\
\hline Ash & $37 \cdot 3$ & $1 \cdot 3$ & $38 \cdot 0$ & $1 \cdot 3$ & $38 \cdot 0$ & 1.0 & $40 \cdot 0$ & 0.6 & 0.070 \\
\hline Glycogen & $1 \cdot 8^{\mathrm{a}}$ & 0.1 & $2 \cdot 5^{\mathrm{b}}$ & 0.2 & $3.4^{\mathrm{C}}$ & 0.1 & $4 \cdot 3^{d}$ & 0.4 & $<0.001$ \\
\hline \multicolumn{10}{|c|}{ Chemical composition of livers ( $\mathrm{g} / \mathrm{kg}$ ) } \\
\hline Crude protein & $144 \cdot 4^{\mathrm{a}}$ & 4.2 & $127 \cdot 4^{\mathrm{b}}$ & 4.2 & $116 \cdot 4^{\mathrm{c}}$ & $4 \cdot 2$ & $109 \cdot 5^{\mathrm{c}}$ & $1 \cdot 1$ & $<0.001$ \\
\hline Crude lipid & $122 \cdot 1$ & $23 \cdot 0$ & $126 \cdot 1$ & $32 \cdot 3$ & $115 \cdot 6$ & $22 \cdot 9$ & $119 \cdot 7$ & $18 \cdot 2$ & 0.960 \\
\hline DM & 328.4 & $21 \cdot 7$ & 375.5 & 83.0 & 334.9 & 1.8 & 341.5 & 5.9 & 0.571 \\
\hline Ash & $15 \cdot 8$ & $3 \cdot 0$ & $12 \cdot 4$ & 1.7 & $12 \cdot 4$ & 1.0 & 11.5 & $0 \cdot 8$ & 0.099 \\
\hline Glycogen & $59 \cdot 0^{a}$ & $9 \cdot 2$ & $77 \cdot 9^{a, b}$ & $20 \cdot 1$ & $98 \cdot 8^{\mathrm{b}, \mathrm{c}}$ & $10 \cdot 1$ & $112 \cdot 6^{\mathrm{c}}$ & $9 \cdot 4$ & 0.004 \\
\hline \multicolumn{10}{|l|}{ Indices (\%) } \\
\hline $\mathrm{HSI}^{*}$ & $1 \cdot 1^{\mathrm{a}}$ & 0.2 & $1 \cdot 2^{\mathrm{a}}$ & 0.4 & $1.6^{\mathrm{b}}$ & 0.4 & $1.7^{\mathrm{b}}$ & 0.4 & $<0.001$ \\
\hline VSI† & $6 \cdot 8$ & 0.7 & $6 \cdot 7$ & $1 \cdot 1$ & $6 \cdot 9$ & 0.9 & $6 \cdot 5$ & 0.7 & 0.298 \\
\hline
\end{tabular}

$\mathrm{HSI}$, hepatosomatic index; VSI, viscerosomatic index.

a,b,c,d Mean values within a row with unlike superscript letters were significantly different $(P<0.05$; Duncan's multiple range test)

${ }^{*} \mathrm{HSI}=\left(\right.$ weight $_{\text {(liver) }} /$ weight $\left._{\text {(whole body }}\right) \times 100$.

$\dagger \mathrm{VSI}=\left(\right.$ weight $_{\text {(viscera) }} /$ weight $\left._{\text {(whole body) }}\right) \times 100$. 


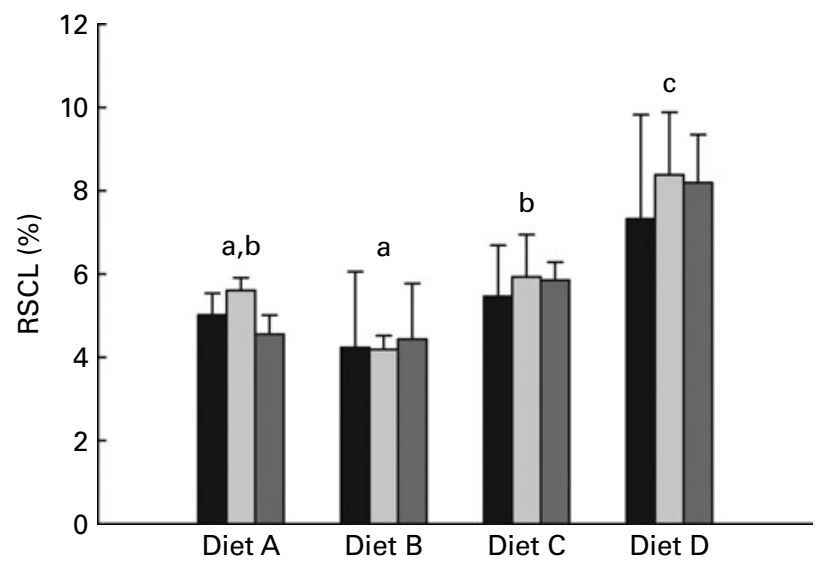

Fig. 2. Percentage of digested starch carbon recovered in lipid carbon fraction of whole fish (RSCL, \%) after being fed the enriched diets for $10(\boldsymbol{\square}), 20$ $(\square)$ and $30 \mathrm{~d}(\square)$. Values are means and standard deviations represented by vertical bars ( $n 3)$. Two-way ANOVA showed significant differences between dietary treatments $(P<0.0001)$, while there were no significant differences between enrichment periods $(P=0.598)$ and there were no interaction between dietary treatment and enrichment period $(P=0.947)$. ${ }^{\mathrm{a}, \mathrm{b}, \mathrm{c}}$ Mean values with unlike letters differed significantly among dietary treatments $(P<0.05$; Duncan's multiple range test).

\section{Hepatosomatic and viscerosomatic indices}

The hepatosomatic index ranged from $1 \cdot 1$ to $1 \cdot 7 \%$, increasing significantly from diets A and B to diets C and D, respectively. There were no significant differences in the viscerosomatic index between dietary treatments (Table 5).

\section{Recovery of carbon originating from starch in whole-body lipid}

The percentage of carbon from dietary starch recovered in the lipid pool of whole fish (RSCL) is presented in Fig. 2. The two-way ANOVA indicate that RSCL was significantly affected by dietary treatment $(P<0.0001)$, but not by the duration of the dietary enrichment period $(P=0.598)$. A multiple comparison analysis subsequently showed that RSCL was significantly lower in fish fed diet B (4.3\%) than in fish fed diets $\mathrm{C}(5.7 \%)$ and $\mathrm{D}(8.0 \%)$. Furthermore, RSCL was significantly lower in fish fed diet A (5.1\%) than in fish fed diet D, while fish fed diet C had significantly lower RSCL than fish fed diet D.

\section{Deposition rate of lipid synthesised from starch}

The deposition rate of lipid synthesised from starch (LDR) is presented in Fig. 3. The LDR ranged from 18.7 to $123.7 \mathrm{mg} /$ $\mathrm{kg}$ biomass per $\mathrm{d}$ in fish fed diets $\mathrm{A}$ and $\mathrm{D}$, respectively. The two-way ANOVA analysis showed that LDR was significantly affected by dietary treatment $(P<0.0001)$, but not by the duration of the dietary enrichment period $(P=0.557)$. The subsequent multiple comparison analysis between dietary treatments showed an increase in LDR with increasing dietary starch, with all dietary treatment groups being significantly different.

\section{Discussion}

The purpose of the present study was to quantify the magnitude of de novo lipogenesis and glycogenesis from dietary starch, when increasing the proportion of DE supplied by starch in diets that were otherwise similar in DP and DE. A secondary objective was to determine the overall importance of dietary starch in glycogen and lipid metabolism.

Simple, high-quality raw material matrices were applied to assure highest possible nutrient quality and avoid possible undesired effects on FI, growth performance and nutrient utilisation of anti-nutrients associated with certain vegetable raw materials $^{(3)}$. Furthermore, the DP:DE ratio of the diets was close to what is considered optimal for feed efficiency and nutrient retention ${ }^{(51)}$, and the essential amino acid composition complied with general recommendations for this species $^{(52,53)}$.

The study clearly demonstrated both de novo lipogenesis and glycogenesis from dietary starch (regardless of inclusion level), as evident from the continuous increase in ${ }^{13} \mathrm{C}$ APE of glycogen and lipid pools of both liver and whole fish tissues (Fig. 1(a)-(d)).

Of the four metabolite pools analysed, the liver glycogen pool displayed the highest enrichment response, with $\mathrm{APE}_{\mathrm{lim}}$ $(t \rightarrow \infty)$ values increasing from $27 \cdot 2$ (diet A) to $68.8 \%$ (diet D) of their respective TME and $t_{95} \%$ values decreasing from 76 to $19 \mathrm{~d}$ with increasing starch levels. The magnitude of the ${ }^{13} \mathrm{C}$ APE response, as well as the relatively low $t_{95} \%$ values observed in this metabolite pool, confirms a rapid and efficient cascade of metabolic events leading to glycogenesis. Furthermore, the decrease in $t_{95} \%$ associated with an increasing dietary starch inclusion level indicates that turnover in this metabolite pool was stimulated by dietary starch. These results support the general perception that both starch

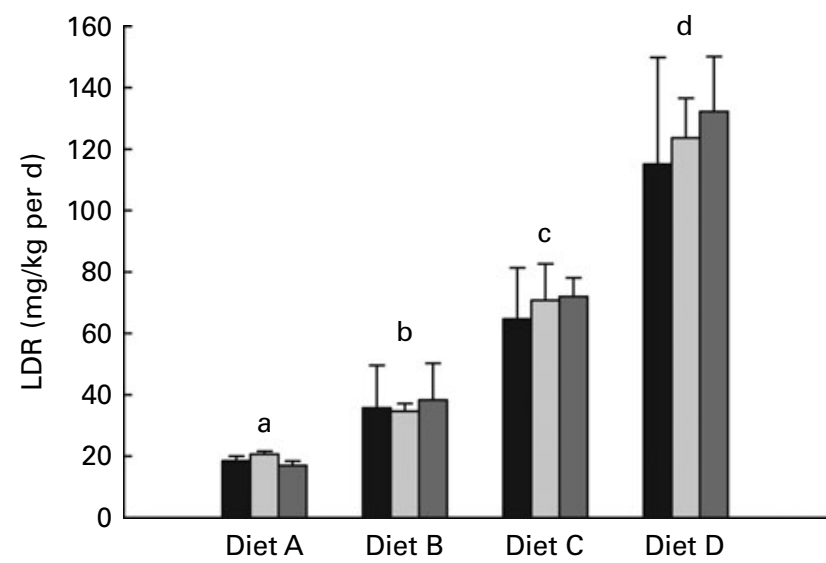

Fig. 3. Deposition rate of lipid derived from starch (LDR, $\mathrm{mg} / \mathrm{kg}$ per d) in fish fed diets containing 6 (diet A), 12 (diet B), 18 (diet C) and $24 \%$ (diet D) starch over three $10 \mathrm{~d}$ feeding periods. Values are means and standard deviations represented by vertical bars ( $n 3)$. Two-way ANOVA showed significant differences between dietary treatments $(P<0.0001)$, while there were no significant differences between enrichment periods $(P=0.557)$ and no interaction between dietary treatment and enrichment period $(P=0.950)$. $a, b, c, d$ Mean values with unlike letters above bars were significantly different among dietary treatments $(P<0.05$; Duncan's multiple range test). $\mathbf{\square}$, Day 10; $\square$, day 20 ; $\square$, day 30. 
digestion $^{(16-18)}$ and the following liver glucose phosphorylation $^{(17,19,20,27,29)}$ (glucose $\rightarrow$ glucose-6-phosphate) are very efficient in gilthead sea bream, even at high dietary starch inclusion levels. The observation that the regression curves for diets C and D (Fig. 1(a)) almost coincided may indicate a near maximum liver glycogen synthesis from dietary starch when including $18-24 \%$ starch in the diet.

The enrichment of the whole-body glycogen pool showed $\mathrm{APE}_{\text {lim }}(t \rightarrow \infty)$ values increasing from 16.5 to $38.8 \%$ of their respective TME, while $t_{95} \%$ values decreased from 103 to $9 \mathrm{~d}$ when feeding diets A to D, respectively. Hence, a very rapid whole-body glycogen turnover $\left(t_{95}=9 \mathrm{~d}\right)$ is apparent at high dietary starch levels (diet D). Interestingly, almost twothirds of the whole-body glycogen and approximately onethird of the liver glycogen must have originated from sources other than dietary starch, even when feeding the high-starch diet (diet D). Similar results were obtained by Viegas et al. ${ }^{(36)}$ for European seabass, finding that as much as $98 \%$ of the blood glucose production could be attributed to gluconeogenesis in both fasted and fed fish. The liver glycogen content was much higher than the whole-body glycogen content (Table 5). Combined with the ${ }^{13} \mathrm{C}$ APE enrichment kinetics in the two pools (Fig. 1(a) and (c)), it therefore appears that hepatically synthesised glycogen contributed significantly to the wholebody glycogen pool, which in addition must have received significant amounts of glycogen from other metabolic processes. Such results might be explained by an apparent lack of gluconeogenesis regulation by dietary carbohydrates in gilthead sea bream, expressed as fructose-1,6-biphosphatase and glucose-6-phosphatase activities, as described earlier ${ }^{(17,19,20,24,27)}$. Combined with glycogenesis from dietary carbohydrates, this appears to produce glycogen at rates that exceed the glycolytic capacity of the fish, causing increases in both hepatosomatic indices and liver glycogen content, as observed in the present and in previous studies when feeding high-carbohydrate diets ${ }^{(14,54,55)}$.

In contrast to the liver and whole-body glycogen pools, the $t_{95 \%}$ of the liver lipid pool appeared to be directly related to dietary starch inclusion level, indicating a reduction of turnover with increasing dietary starch level. However, considering the very weak ${ }^{13} \mathrm{C}$ APE response and relatively low $r^{2}$ of the regression for fish fed diet $\mathrm{A}$, the associated $t_{95} \%$ value (i.e. $15 \mathrm{~d}$ ) should probably be disregarded, leaving the $t_{95 \%}$ range between 44 and $51 \mathrm{~d}$ for fish fed diets $\mathrm{B}$ and $\mathrm{D}$, respectively.

Similar to the whole-body glycogen pool, hepatically synthesised lipid from starch seemed to be directed towards the whole-body lipid pool. This was apparent from the approximately five-fold higher ${ }^{13} \mathrm{C}$ APE found in the liver lipid pool compared with the whole-body lipid pool, and the linear enrichment kinetics seen in whole-body lipid, which indicate a passive storage function in the latter. After $30 \mathrm{~d}$ of dietary ${ }^{13} \mathrm{C}$ starch enrichment, a maximum of $2 \cdot 8 \%$ of the whole-body lipid carbon pool was of starch origin (calculated from the regression coefficients given in Table 3), corresponding to approximately $8.7 \%$ of the total whole-body lipid deposited during the $30 \mathrm{~d}$. Thus, a relatively small proportion of the whole-body lipid deposition could be attributed to lipogenesis from dietary starch, even at high dietary carbohydrate levels. This is also apparent when considering the low efficiency $(4 \cdot 2-8 \cdot 4 \%)$ with which starch carbon was recovered in the whole-body lipid fraction of the fish (RSCL; Fig. 2). Hence, more than $90 \%$ of the digested starch must have been used for purposes other than lipogenesis, regardless of dietary treatment. Interestingly, the RSCL seemed to increase when increasing the dietary starch content (Fig. 2), meaning that the actual amount of starch carbon recovered in the lipid fraction of fish fed diet D compared with the fish fed diet A was approximately eight-fold higher. This is also apparent from Fig. 3, which shows that the deposition rate of lipid (LDR) originating from starch increased from 18.7 to $123.7 \mathrm{mg} / \mathrm{kg}$ biomass per $\mathrm{d}$ when dietary starch increased from 6 to $24 \%$. This confirms that de novo lipogenesis from dietary carbohydrates was subject to regulation based on the dietary carbohydrate level, consistent with earlier studies which found a strong correlation between dietary carbohydrate level and enzyme activity related to lipogenesis ${ }^{(24,28,54,56,57)}$ (i.e. the activity of glucose-6-phosphate dehydrogenase). Despite the fact that de novo lipogenesis from dietary carbohydrates was indeed active and apparently subject to nutritional control, the contribution to the overall lipid deposition appeared to have been modest in the present study. Hence, Fig. 4 presents lipid budgets of the four dietary treatment groups. The figure shows that the maximum contribution to lipid deposition from dietary starch was $12.3 \mathrm{~g}$ of lipid out of a total deposition of approximately $150 \mathrm{~g}$ when gaining $1 \mathrm{~kg}$ of biomass (fish fed diet D). The figure also shows that when feeding the highest starch levels (diet D), the total lipid deposition exceeded the sum of digested lipid and deposition from de novo synthesised lipid from starch. Thus, fish fed diet D would not even theoretically have been able to cover their total lipid deposition from dietary lipid and starch sources combined. Consequently, this lipid 'deficit' must have originated from de novo lipid synthesis, presumably using protein as a carbon donor. This agrees with the stimulating effect of excess dietary protein on glucose-6-phosphate dehydrogenase activity found by

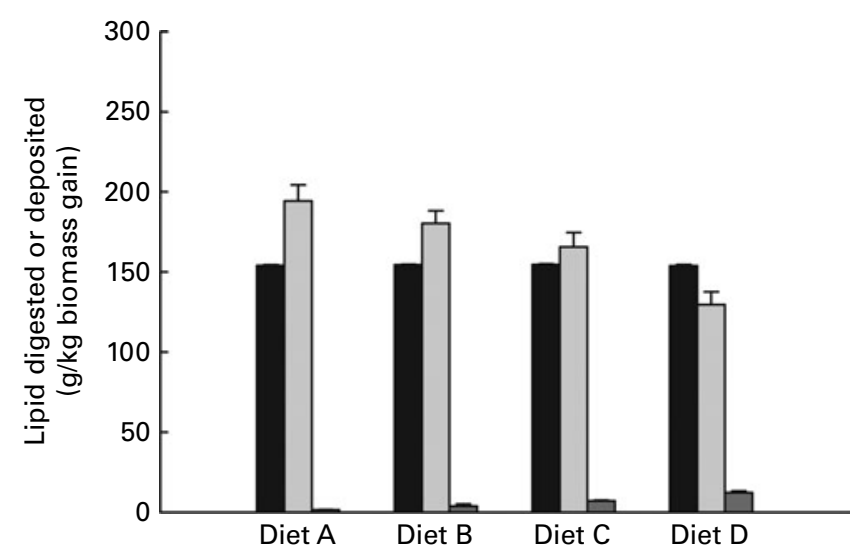

Fig. 4. Lipid budget when accreting $1 \mathrm{~kg}$ of biomass (lipid deposited or digested, g) in fish fed diets containing $6(\operatorname{diet} A), 12(\operatorname{diet} B), 18(\operatorname{diet} C)$ and $24 \%$ (diet D) starch. Values are means and standard deviations represented by vertical bars $(n 3)$. $\mathbf{n}$, Total lipid deposition; $\square$, lipid digested; $\square$, lipid of starch origin deposited. 
Enes et $a l^{(17)}$ and the inherently poor protein retention reported for this species compared with species like salmonids.

The overall growth and feed performance results, as well as the daily FI, were not significantly affected by dietary treatment, despite the fact that dietary $\mathrm{DE}$ increased by $1 \mathrm{MJ} / \mathrm{kg}$ (approximately 5.6\%) from diet A $(17.9 \mathrm{MJ} / \mathrm{kg})$ to $\operatorname{diet} \mathrm{D}$ $(18.9 \mathrm{MJ} / \mathrm{kg})$. As increasing levels of dietary starch has been shown to negatively affect feed efficiency ${ }^{(21)}$, this may have masked any effects that the slightly increased DE levels may have had on performance results in the present study. In addition, the growth period ( $30 \mathrm{~d}$ of feeding, corresponding to approximately $45 \%$ biomass increase) may have been too short to demonstrate significant differences in these parameters.

Fish fed diet D showed significantly better protein ADC than fish fed the remaining diets, which might have been an effect of the lower dietary cellulose content of this diet, although negative effects of dietary cellulose on protein digestibility have not been reported for other species fed diets with cellulose inclusion levels up to $20 \%{ }^{(58-60)}$. The very high starch ADC observed in the present study (96.5-99.6\%) and the inverse relationship between starch ADC and dietary starch level has been reported previously in both gilthead sea bream and European seabass ${ }^{(16-18,54)}$. Ideally, analyses on dietary and faecal nutrient compositions used for ADC assessments should be carried out using identical protocols for both types of samples. However, the scarce amount of faecal matter available for analyses precluded use of the Kjeldahl method ${ }^{(39)}$ for protein analysis and the Bach Knudsen method ${ }^{(46)}$ for starch analysis on faecal samples. Thus, faecal starch content was determined using a BioVision starch assay kit and faecal protein was determined using elemental analysis.

Prior to the present study, the fish had formed part of a feeding trial, where they had been fed four diets similar to the experimental diets used here, except for the addition of ${ }^{13} \mathrm{C}$ starch. Thus, fish had grown from an average weight of approximately 25 to $75 \mathrm{~g}$ (unlabelled diets; pre-study) and further from 75 to $100 \mathrm{~g}$ (labelled diets; present study), corresponding to a quadruplication of body weight on these diets. Despite this, whole-body protein, lipid, ash and DM did not differ significantly among fish fed the four experimental diets. Thus, the increasing dietary starch inclusion level did not affect the body composition, which is more or less in accordance with earlier findings ${ }^{(21)}$. Yet, some studies have found a positive relationship between dietary digestible carbohydrate and body lipid levels ${ }^{(17,24,28)}$, while others have found body lipid levels to be unaffected by both macronutrient ratios in iso-DE diets ${ }^{(21)}$ and dietary energy level ${ }^{(61)}$. Only wholebody glycogen content was significantly elevated (from $1 \cdot 8$ to $4.3 \mathrm{~g} / \mathrm{kg}$ ) when increasing the dietary starch level. Liver lipid, ash and DM were not significantly affected by dietary treatment, while liver protein decreased (from 144.4 to $109.5 \mathrm{~g} / \mathrm{kg}$ ) and liver glycogen increased (from 59.0 to $112.6 \mathrm{~g} / \mathrm{kg}$ ) in what resembled a $1: 1$ substitution of protein with glycogen when increasing dietary starch level. Also, hepatosomatic indices were significantly affected by the dietary treatment, increasing from 1.1 to $1.7 \%$ in fish fed diets A and $\mathrm{D}$, respectively. Similar results have been reported in both gilthead sea bream and other species when increasing digestible dietary carbohydrate intake ${ }^{(14,54,55)}$.

\section{Conclusion}

For the first time, long-term oral administration of ${ }^{13} \mathrm{C}$-labelled starch has been applied to determine the role of dietary starch on glycogenesis and de novo lipogenesis in gilthead sea bream. The study corroborated the earlier reported high ADC of processed/extruded starches ${ }^{(16-18)}$ followed by efficient glycogenesis. Also, endogenously produced glycogen from other metabolic processes (e.g. amino acid catabolism) seemed to contribute significantly to the total glycogen production of the fish, regardless of dietary treatment. This could potentially be attributed to lack of dietary regulation of fructose-1,6-biphosphatase $\mathrm{e}^{(17,19,20,24,27)}$, continuously diverting non-carbohydrate metabolites of the glycolytic pathway in the direction of glycogenesis. The combined endogenic and dietary contribution to glycogenesis appeared to have caused an accumulation of glycogen in both whole fish and liver tissues, causing hepatomegaly in fish fed highstarch diets. Also, de novo lipogenesis from dietary starch was proven to be active and under apparent nutritional control. However, a maximum of $8.4 \%$ of the digested starch carbon could be recovered in the lipid fraction of the fish, indicating that dietary starch seemed to play only a minor role in the overall lipid budget of gilthead sea bream. Considering the significant contribution of non-carbohydrate metabolites (most likely originating from protein catabolism) to glycogenesis, and the apparent 'deficit' in the lipid budget presented, the results strongly hint that dietary protein may play a major role not only for anabolic purposes, but also for short-term (glycogen) and long-term (lipid) energy storage purposes in gilthead sea bream, which in turn could explain the relatively poor protein retention typically found in the this species.

\section{Acknowledgements}

The authors would like to thank the technical and laboratory staff at DTU Aqua, Hirtshals, Denmark; BioMar A/S's trial station, Hirtshals, Denmark; and Risø DTU, Roskilde, Denmark for invaluable help during experimentation and analytical work. The work was part of K. S. E.'s PhD study, sponsored by the DTU Aqua and the BioMar A/S, Denmark. Authors responsibilities were as follows: all authors helped to plan the research; K. S. E. was responsible for the biological trials, performed laboratory work and analysed the data; all authors helped to interpret results; K. S. E. wrote the manuscript; all authors helped to proofread the manuscript. There are no conflicts of interest to report.

\section{References}

1. Wurts WA (2000) Sustainable aquaculture in the twenty-first century. Rev Fish Sci 8, 141-150.

2. Pillay TVR (editor) (2004) Aquaculture and the Environment, 2nd ed. Oxford: Blackwell Publishing Limited. 
3. Gatlin DM III, Barrows FT, Brown P, et al. (2007) Expanding the utilization of sustainable plant products in aquafeeds: a review. Aquacult Res 38, 551-579.

4. Corraze G \& Kaushik S (2009) Lipid nutrition and fish oil replacement by vegetable oils in pisciculture. Cab Agric 18, $112-118$

5. Turchini GM, Torstensen BE \& Ng W (2009) Fish oil replacement in finfish nutrition. Rev Aquacult 1, 10-57.

6. Bureau D, Harris A \& Cho C (1999) Apparent digestibility of rendered animal protein ingredients for rainbow trout (Oncorbynchus mykiss). Aquaculture 180, 345-358.

7. El-Haroun ER, Azevedo PA \& Bureau DP (2009) High dietary incorporation levels of rendered animal protein ingredients on performance of rainbow trout Oncorbynchus mykiss (Walbaum, 1972). Aquaculture 290, 269-274.

8. Kiessling A \& Askbrandt S (1992) Nutritive value of 2 bacterial strains of single-cell protein for rainbow trout (Oncorhynchus mykiss). Aquaculture 109, 119-130.

9. Perera W, Carter C \& Houlihan D (1995) Feed consumption, growth and growth efficiency of rainbow trout (Oncorbynchus mykiss (Walbaum)) fed on diets containing a bacterial single-cell protein. Br J Nutr 73, 591-603.

10. Aas TS, Hatlen B, Grisdale-Helland B, et al. (2006) Effects of diets containing a bacterial protein meal on growth and feed utilisation in rainbow trout (Oncorbynchus mykiss). Aquaculture 261, 357-368.

11. Tacon AGJ \& Metian M (2008) Global overview on the use of fish meal and fish oil in industrially compounded aquafeeds: trends and future prospects. Aquaculture 285, 146-158.

12. Welch A, Hoenig R, Stieglitz J, et al. (2010) From fishing to the sustainable farming of carnivorous marine finfish. Rev Fish Sci 18, 235-247.

13. Salta E, Panagiotidis C, Teliousis K, et al. (2009) Evaluation of the possible transmission of BSE and scrapie to gilthead sea bream (Sparus aurata). PLOS ONE 4, e6175.

14. Hemre GI, Mommsen TP \& Krogdahl A (2002) Carbohydrates in fish nutrition: effects on growth, glucose metabolism and hepatic enzymes. Aquacult Nutr 8, 175-194.

15. Stone D (2003) Dietary carbohydrate utilization by fish. Rev Fish Sci 11, 337-369.

16. Couto A, Enes P, Peres H, et al. (2012) Temperature and dietary starch level affected protein but not starch digestibility in gilthead sea bream juveniles. Fish Physiol Biochem 38, 595-601.

17. Enes P, Panserat S \& Kaushik S (2008) Growth performance and metabolic utilization of diets with native and waxy maize starch by gilthead sea bream (Sparus aurata) juveniles. Aquaculture 274, 101-108.

18. Venou B, Alexis MN, Fountoulaki E, et al. (2003) Effect of extrusion of wheat and corn on gilthead sea bream (Sparus aurata) growth, nutrient utilization efficiency, rates of gastric evacuation and digestive enzyme activities. Aquaculture 225, 207-223.

19. Enes P, Panserat S, Kaushik S, et al. (2008) Hepatic glucokinase and glucose-6-phosphatase responses to dietary glucose and starch in gilthead sea bream (Sparus aurata) juveniles reared at two temperatures. Comp Biochem Phys A 149, 80-86.

20. Enes P, Panserat S, Kaushik S, et al. (2008) Rearing temperature enhances hepatic glucokinase but not glucose-6-phosphataseactivities in European sea bass (Dicentrarchus labrax) and gilthead sea bream (Sparus aurata) juveniles fed with the same level of glucose. Comp Biochem Phys $A$ 150, 355-358

21. Couto A, Enes P, Peres H, et al. (2008) Effect of water temperature and dietary starch on growth and metabolic utilization of diets in gilthead sea bream (Sparus aurata) juveniles. Comp Biochem Phys A 151, 45-50.

22. Peres H, Goncalves P \& Oliva-Teles A (1999) Glucose tolerance in gilthead seabream (Sparus aurata) and European seabass (Dicentrarchus labrax). Aquaculture 179, 415-423.

23. Adamidou S, Nengas I, Henry M, et al. (2011) Effects of dietary inclusion of peas, chickpeas and faba beans on growth, feed utilization and health of gilthead seabream (Sparus aurata). Aquacult Nutr 17, E288-E296.

24. Meton I, Mediavilla D, Caseras A, et al. (1999) Effect of diet composition and ration size on key enzyme activities of glycolysis-gluconeogenesis, the pentose phosphate pathway and amino acid metabolism in liver of gilthead sea bream (Sparus aurata). Br J Nutr 82, 223-232.

25. Meton I, Caseras A, Fernandez F, et al. (2000) 6-Phosphofructo-2-kinase/fructose-2,6-bisphosphatase gene expression is regulated by diet composition and ration size in liver of gilthead sea bream, Sparus aurata. Biochim Biophys Acta 1491, 220-228.

26. Caseras A, Meton I, Fernandez F, et al. (2000) Glucokinase gene expression is nutritionally regulated in liver of gilthead sea bream (Sparus aurata). Biochim Biophys Acta 1493, $135-141$

27. Caseras A, Meton I, Vives C, et al. (2002) Nutritional regulation of glucose-6-phosphatase gene expression in liver of the gilthead sea bream (Sparus aurata). Br J Nutr 88, 607-614

28. Fernandez F, Miquel AG, Cordoba M, et al. (2007) Effects of diets with distinct protein-to-carbohydrate ratios on nutrient digestibility, growth performance, body composition and liver intermediary enzyme activities in gilthead sea bream (Sparus aurata, L.) fingerlings. J Exp Mar Biol Ecol 343, $1-10$.

29. Panserat S, Medale F, Blin C, et al. (2000) Hepatic glucokinase is induced by dietary carbohydrates in rainbow trout, gilthead seabream, and common carp. Am J Physiol Regul Integr Comp Physiol 278, R1164-R1170.

30. Felip O, Ibarz A, Fernández-Borràs J, et al. (2012) Tracing metabolic routes of dietary carbohydrate and protein in rainbow trout (Onchorynchus mykiss) using stable isotopes $\left(\left[{ }^{13} \mathrm{C}\right]\right.$ starch and $\left[{ }^{15} \mathrm{~N}\right]$ protein): effects of gelatinization of starches and sustained swimming. Br J Nutr 107, 834-844.

31. Schoenheimer R \& Rittenberg D (1935) Deuterium as an indicator in the study of intermediary metabolism. Science 82, 156-157.

32. Hemre GI \& Kahrs F (1997) ${ }^{14} \mathrm{C}$-glucose injection in Atlantic cod, Gadus morbua, metabolic responses and excretion via the gill membrane. Aquacult Nutr 3, 3-8.

33. Brauge C, Corraze G \& Medale F (1995) Effects of dietary levels of carbohydrate and lipid on glucose oxidation and lipogenesis from glucose in rainbow trout, Oncorbynchus mykiss, reared in fresh water or in seawater. Comp Biochem Phys $A$ 111, 117-124.

34. Fraser KPP, Lyndon AR \& Houlihan DF (1998) Protein synthesis and growth in juvenile Atlantic halibut, Hippoglossus hippoglossus (L.): application of ${ }^{15} \mathrm{~N}$ stable isotope tracer. Aquacult Res 29, 289-298.

35. Hemre G \& Storebakken T (2000) Tissue and organ distribution of C-14 activity in dextrin adapted Atlantic salmon after oral administration of radiolabelled C-14(1)-glucose. Aquacult Nutr 6, 229-234.

36. Viegas I, Mendes VM, Leston S, et al. (2011) Analysis of glucose metabolism in farmed European sea bass (Dicentrarchus labrax L.) using deuterated water. Comp Biochem Phys A 160, 341-347. 
37. Austreng E (1978) Digestibility determination in fish using chromic oxide marking and analysis of contents from different segments of gastrointestinal tract. Aquaculture 13, 265-272.

38. European Commission (1986) Council Directive 86/609/EEC of 24 November 1986 on the Approximation of Laws, Regulations and Administrative Provisions of the Member States regarding the Protection of Animals used for Experimental and Other Scientific Purposes.

39. ISO (2005) Animal Feeding Stuffs - Determination of Nitrogen Content and Calculation of Crude Protein Content Part 2: Block Digestion/Steam Distillation Method no. ISO 5983-2:2005. Geneva: ISO.

40. Bligh EG \& Dyer WJ (1959) A rapid method of total lipid extraction and purification. Can J Biochem Physiol 37, 911-917.

41. Kolar K (1992) Gravimetric determination of moisture and ash in meat and meat products - NMKL Interlaboratory Study. J AOAC Int 75, 1016-1022.

42. ISO (1998) Water Quality - Determination of 33 Elements by Inductively Coupled Plasma Atomic Emission Spectroscopy no. ISO 11885. Geneva: ISO.

43. DS (Danish Standards) (2002) Foodstuffs - Determination of Trace Elements - Pressure Digestion no. DS/EN 13805:2002. Charlottenlund: DS

44. European Commission (2009) Commission Regulation (EC) no 152/2009 of 27 January 2009 Laying Down the Methods of Sampling and Analysis for the Official Control of Feed (Text with EEA Relevance).

45. ISO (2005) ISO 13904:2005 Animal Feeding Stuffs Determination of Tryptophan Content.

46. Bach Knudsen KE (1997) Carbohydrate and lignin contents of plant materials used in animal feeding. Anim Feed Sci Technol 67, 319-338.

47. Good C, Kramer H \& Somogyi M (1933) The determination of glycogen. J Biol Chem 100, 485-491.

48. Craig H (1957) Isotopic standards for carbon and oxygen and correction factors for mass spectrometric analysis of carbon dioxide. Geochim Cosmochim Acta 12, 133-149.

49. Duncan D (1955) Multiple range and multiple $F$ tests. Biometrics 11, 1-42.

50. Windell J, Foltz J \& Sarokon J (1978) Effect of fish size, temperature, and amount fed on nutrient digestibility of a pelleted diet by rainbow trout, Salmo Gairdneri. Trans Am Fish Soc 107, 613-616.

51. Santinha PJM, Medale F, Corraze G, et al. (1999) Effects of the dietary protein: lipid ratio on growth and nutrient utilization in gilthead seabream (Sparus aurata L.). Aquacult Nutr 5, 147-156.

52. Kaushik S (1998) Whole body amino acid composition of European seabass (Dicentrarchus labrax), gilthead seabream (Sparus aurata) and turbot (Psetta maxima) with an estimation of their IAA requirement profiles. Aquat Living Resour 11, 355-358.

53. Peres H \& Oliva-Teles A (2009) The optimum dietary essential amino acid profile for gilthead seabream (Sparus aurata) juveniles. Aquaculture 296, 81-86.

54. Enes P, Panserat S, Kaushik S, et al. (2011) Dietary carbohydrate utilization by European sea bass (Dicentrarchus labrax L.) and gilthead sea bream (Sparus aurata L.) juveniles. Rev Fish Sci 19, 201-215.

55. Enes P, Panserat S, Kaushik S, et al. (2009) Nutritional regulation of hepatic glucose metabolism in fish. Fish Physiol Biochem 35, 519-539.

56. Enes P, Panserat S, Kaushik S, et al. (2006) Effect of normal and waxy maize starch on growth, food utilization and hepatic glucose metabolism in European sea bass (Dicentrarchus labrax) juveniles. Comp Biochem Phys $A$ 143, 89-96.

57. Enes P, Peres H, Couto A, et al. (2010) Growth performance and metabolic utilization of diets including starch, dextrin, maltose or glucose as carbohydrate source by gilthead sea bream (Sparus aurata) juveniles. Fish Physiol Biochem 36, 903-910.

58. Dias J, Huelvan C, Dinis MT, et al. (1998) Influence of dietary bulk agents (silica, cellulose and a natural zeolite) on protein digestibility, growth, feed intake and feed transit time in European seabass (Dicentrarchus labrax) juveniles. Aquat Living Resour 11, 219-226.

59. Hansen JO \& Storebakken T (2007) Effects of dietary cellulose level on pellet quality and nutrient digestibilities in rainbow trout (Oncorbynchus mykiss). Aquaculture 272, $458-465$.

60. Lekva A, Hansen A, Rosenlund G, et al. (2010) Energy dilution with alpha-cellulose in diets for Atlantic cod (Gadus morhua L.) juveniles - effects on growth, feed intake, liver size and digestibility of nutrients. Aquaculture 300, 169-175.

61. Bonaldo A, Isani G \& Fontanillas R (2010) Growth and feed utilization of gilthead sea bream (Sparus aurata, L.) fed to satiation and restrictively at increasing dietary energy levels. Aquacult Int 18, 909-919.

62. Subcommittee on Fish Nutrition \& National Research Council (1993) Nutrient Requirements of Fish. Washington, DC: National Academy Press.

63. McArdle WD, Katch FI \& Katch VL (2006) Essentials of Exercise Physiology, 3rd ed. Philadelphia, PA: Lippincott Williams \& Wilkins.

64. Hopkins KD (1992) Reporting fish growth: a review of the basics. J World Aquac Soc 23, 173-179.

65. Maynard LA \& Loosli JK (1969) Animal Nutrition, 6th ed. New York: McGraw-Hill Book Company. 